\title{
Activating mutations of the thyrotropin receptor: a short review with emphasis on some pediatric aspects
}

\author{
Michel Polak \\ Service d'Endocrinologie et de Diabétologie Pédiatriques, Hôpital Robert Debré, 48 Boulevard Sérurier, 75019 Paris, France
}

\section{Introduction: the thyrotropin receptor}

The thyrotropin (TSH) receptor belongs to a subfamily of $\mathrm{G}$ protein coupled receptors. The primary structure of this protein predicts the existence of seven segments with hydropathy compatible with a transmembrane location (1). The binding specificity and the effector properties of the TSH receptor are encoded in separate domains of the proteins; the extracellular part is involved in the binding of TSH and the transmembrane domain has the effector properties triggering $\mathrm{G}$ protein activation (2). The gene organization reflects these dual functions, as a single exon encodes the transmembrane domain whereas the rest of the extracellular domain is encoded for by nine exons (3).

Recently, gain of function mutations have been described in the TSH receptor, which explain some pathological conditions in humans $(4,5)$. This article discusses the responsibility of such mutations of the TSH receptor in hyperthyroidism; in the first part is described the phenotypes of the patient with special emphasis on familial and sporadic congenital hyperthyroidism caused by germline mutations, as well as the distinction between them and the somatic mutations which have been found in thyroid adenomas. The available in vitro or in vivo studies which confirm that the mutations are responsible for the phenotype are then reviewed. This review will focus on the clinical consequences of TSH receptor mutations, particularly in the setting of congenital hyperthyroidism, and provide a follow-up on the case previously described (6), rather than discuss the implications for the basic understanding of the structure and function of the TSH receptor. Other aspects of diseases linked to TSH receptor mutations, among which is the controversy linking thyroid neoplasms and such mutations, have been reviewed very recently (7).

\section{The transducing system of the TSH receptor}

Upon binding of TSH to its receptor, the main pathway of the signal transduction involves the activation of the adenylate cyclase through $\mathrm{G}$ protein coupling and the intracellular production of cAMP $(8-11)$. The phospholipase C-diacylglycerol regulatory pathway is also activated, although at hormone concentrations five to ten times higher than the cAMP pathway (9-11). The cAMP pathway has been shown to be important for the positive control of thyroid hormone secretion and growth of the thyrocytes, whereas the inositol phosphate pathway seems mostly involved in the control of iodination and hormone synthesis $(2,12)$.

Since the TSH receptor has a central role in the control of human thyroid follicular cell proliferation and function, it is therefore expected that its deregulation would lead to pathological processes.

\section{Activating mutations of the TSH receptor and hyperthyroidism phenotypes caused by somatic mutations}

Autonomously functioning nodules may occur as solitary or multiple nodules leading to hyperthyroidism. The coexistence of autonomous and quiescent tissue in the same organ suggests an inherent defect in the pathological tissue. The observation of hyperthyroidism and independent growth of hot nodules suggests a chronic activation of the cAMP cascade which controls growth and function of thyroid follicular cells. The first mutations of the TSH receptor leading to toxic adenomas were described in the third intracellular loop of the receptor (13). Further mutations were subsequently identified $(14,15)$. The frequency of TSH receptor mutations in toxic nodules may be variable for technical reasons, direct sequencing being more sensitive than single strand conformation polymorphism analysis. In addition, most studies analyzed only a small fragment of the receptor and mutations in other parts of the receptor may have been missed $(16,17)$. With the entire sequencing of the transmembrane domain, 9 out of 11 toxic nodules were found to harbor TSH receptor mutations (18). The exact frequency of these mutations remains to be established, as a recent study, using direct sequencing, found only $20 \%$ of the nodules ( 9 out of 44 ) harboring TSH receptor mutations, whereas another confirmed the author's previous publication with $82 \%$ of nodules (27 out of 33) harboring TSH receptor mutations $(19,20)$.

\section{Phenotypes in congenital mutations}

Following the discovery of TSH receptor gene mutations in toxic thyroid adenomas (13), such mutations were 
searched for in sporadic congenital and familial nonautoimmune hyperthyroidism.

Familial congenital non-autoimmune hyperthyroidism with thyroid hyperplasia (autosomal dominant toxic thyroid hyperplasia (ADTTH)) due to germline mutations of the TSH receptor gene have been reported (4, 21-24). The characteristics of the cases of ADTTH described up to 1997 have been reviewed by Leclère (24). In the five analyzed kindreds, 49 out of 120 examined patients were found to have hyperthyroidism. Remarkably, women were affected more frequently in these series ( 32 women versus 17 men). The onset of thyrotoxicosis was early, but varied from 1 year of age to $10,14,17$ and 23 years depending on the family. Interestingly, a systematic screening of the families revealed two unsuspected children with decreased TSH and no signs of hyperthyroidism, emphasizing the potential of detecting affected children before the appearance of the disease and its potential deleterious consequences (24). The goiters were homogenously diffuse in children, but tended to become multinodular later in life. No ophthalmopathy was detected and this was an important diagnostic criterion, even though our case (see below) illustrates that exophthalmia should not be an exclusion criterion for the diagnosis of nonautoimmune hyperthyroidism $(6,24)$. No circulating antithyroid antibodies, including anti-TSH receptor antibodies as searched for by binding or functional assays, were detected in those patients. Recurrence after antithyroid drug therapy, non-ablative radioiodine treatment or partial thyroidectomy was frequent. Pathological studies of thyroid glands from patients with ADTTH were distinct from those of autoimmune Graves' disease as no mononuclear cells were infiltrating the thyroid and as none of the usual autoimmune markers of Graves' immunohistology were present (24). In conclusion the diagnosis of non-autoimmune hyperthyroidism with thyroid hyperplasia should be considered in the presence of: a history of familial thyrotoxicosis; a high incidence and early occurrence of the disease; moderate and diffuse goiter (only in young people and not in the case of recurrence); absence of extrathyroidal signs of Graves' disease (proptosis should not be an exclusion criterion); absence of circulating thyroid antibodies; and recurrence after medical treatment, non-ablative surgery or destruction of the thyroid with radioisotopes (24).

Non-familial congenital non-autoimmune hyperthyroidism with thyroid hyperplasia due to sporadic mutation of the TSH receptor gene (Phe631Leu) was first described by Kopp et al. (25) as neonatal hyperthyroidism, diffuse goiter, markedly advanced bone age, and persistently low head circumference associated with psychomotor delay. After an 8 year course of antithyroid drug, thyroidectomy was performed due to recurrence of hyperthyroidism with an increase in goiter size and the appearance of multiple thyroid nodules. Recurrence of thyrotoxicosis after subtotal thyroidectomy led to radioiodine treatment which restored euthyroidism (25).

Subsequently, my colleagues and I reported a case of neonatal hyperthyroidism without stimulatory TSH receptor antibodies (TSab) (6). This patient was a small-for-date premature boy, born at 32.5 weeks of gestation from a normal mother. Pregnancy was uneventful except for fetal tachycardia noticed at 31 weeks of gestation. Hepatosplenomegaly, lymphadenopathy and petechiae, as well as thrombocytopenia and hepatic cholestasis, developed during the early days of life, and extensive investigations excluded viral or bacterial perinatal infection. At 6 days of life, thyromegaly and eyelid retraction were prominent and diagnosis of neonatal hyperthyroidism was made (free thyroxine $>100 \mathrm{pmol} / \mathrm{l}$, free tri-iodothyronine $>35 \mathrm{pmol} / \mathrm{l}$, TSH $<0.1 \mathrm{IU} / \mathrm{l}$, TSab negative). Advanced bone age at birth and elevated cord blood thyroid hormone levels indicated that hyperthyroidism was indeed present during fetal life. The absence of any known thyroid disease, normal thyroid hormone levels and the lack of TSab in the mother led us to suspect a non-immune etiology. Genomic sequencing of the last exon of the TSH receptor in the patient revealed a transversion resulting in a heterozygous substitution of one amino acid in the second transmembrane domain of the receptor (Met453Thr, Fig. 1). This substitution was shown to confer constitutive activity to the mutated receptor in in vitro studies (see below and Fig. 2). The child was treated with carbimazole from post-natal day 11; euthyroidism was achieved and regression of hepatosplenomegaly, polyadenopathy and cholestasis was noticed and a satisfactory weight gain obtained. L-Thyroxine was added at 7 months to prevent hypothyroidism. Thereafter euthyroidism was maintained

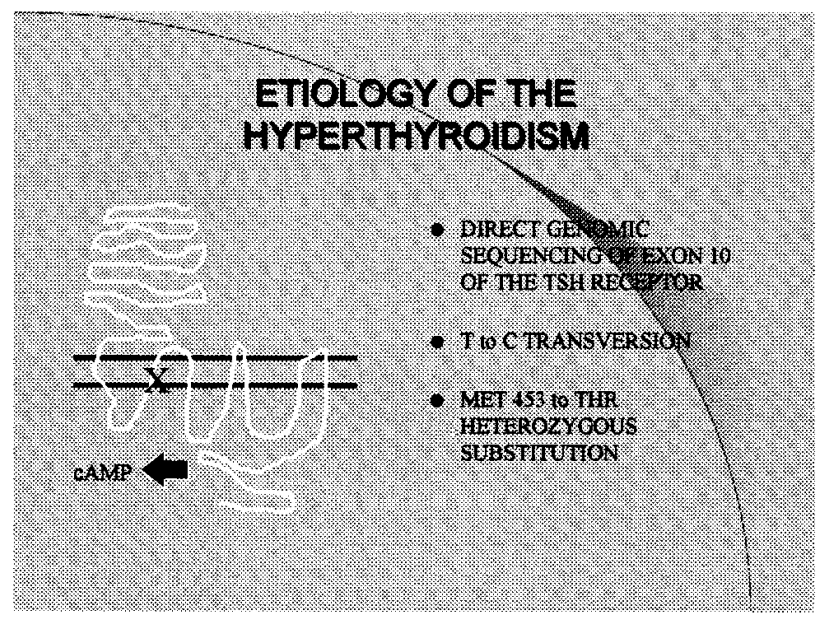

Figure 1 Schematic representation of the localization of the amino acid change in the mutated TSH receptor, in the second transmembrane domain $(\mathrm{X})$ leading to the constitutive activation of the $\mathrm{TSH}$ receptor and increased production of cAMP in the described case (see text and (6)) 


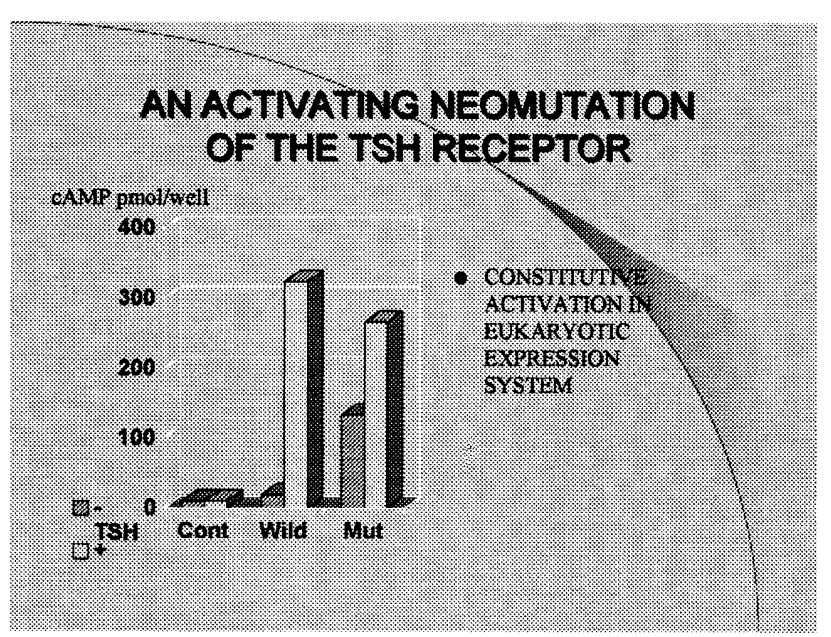

Figure 2 Data demonstrating the increased cAMP production in the transfection experiments in the described case. Basal cAMP production was increased when the mutated cDNA coding for the TSH receptor was transfected (Mut) as compared with the wild type cDNA coding for the TSH receptor (Wild). Control (Cont) transfections were accomplished by transfecting the vector without the cDNA coding for the TSH receptor. Mut retained partial ability to respond to TSH stimulation, in comparison with Wild (see text and (6)).

with both drugs until the last follow-up visit at 3 years of age, but TSH remained suppressed until 12 months of post-natal age. Hyperthyroidism is not cured at present as intermittent removal of antithyroid drugs led to recurrence of the thyrotoxicosis.

No craniosynostosis was noticed in this child. No developmental impairments were noted during the first year. However, quantitative evaluation of the development, with the Brunet-Lezine test, conducted at 3 years of age revealed a developmental delay of a year, with a developmental age of 24 months. Motricity and behavior were normal. Interestingly, in the case described by Kopp et al. (25), or in a more recent case described by Holzapfel et al. (26) (where a child with a sporadic congenital hyperthyroidism due to a mutation resulting in a heterozygous substitution of one amino acid in the third transmembrane domain of the receptor (Ser505Asn) was found to have persistent speech disturbances), developmental impairments were found in association with microcephaly. Indeed our case emphasizes the potential deleterious effect of fetal hyperthyroidism, independently of the presence of craniostenosis and/or microcephaly.

This child presented also with exophthalmia, documented by CT scan and NMR, even though no sign of thyroid autoimmunity was present. He was euthyroid at the time of these examinations and the parents did not have exophthalmia. Moreover, at 3 years of age, in a euthyroid state, exophthalmia is still present and documented at the NMR of the eyes, even though there is no enlargement of the eye muscles. The expression of the TSH receptor in retroorbital tissue might therefore be involved in the pathogenesis of exophthalmia in Graves' disease (27).

Very recently, constitutive activation of the TSH receptor caused by mutations of the extracellular and not the transmembrane domain were described in toxic adenomas by the Brussels group (28). In addition, following the description of non-autoimmune hyperthyroidism due to mutations in the transmembrane domain of the receptor, Kopp et al. (29) reported a case of an activating mutation in the extracellular TSH-binding domain in a male infant with congenital hyperthyroidism due to a toxic adenoma. This shows clearly that activating mutations are not limited to exon 10 of the TSH receptor gene (28-30).

Taken together, constitutive activation of the TSH receptor due to neomutations in the gene is a possible, although rare, etiology of persistent neonatal hyperthyroidism, which may develop during fetal life. It should be suspected in the absence of maternal signs of thyroid autoimmunity $(6,23,25,29,30)$. These TSH receptor gene mutations are likely to be the explanation for some cases of familial persistent neonatal hyperthyroidism described more than 20 years ago $(31,32)$.

\section{In vitro and in vivo studies confirm the stimulatory nature of the TSH receptor mutation}

Most of the published articles have used sequencing of PCR-amplified fragments of exon 10 of the TSH receptor gene, because this single exon encodes the transmembrane domain. The rationale for this approach was that the likelihood of finding activating mutations in this domain was high because it is involved in signal transduction, as demonstrated by studies with the alpha1-adrenergic receptor $(6,13,22,25,33)$. The wild type and the mutated receptor gene were then transiently transfected in eukaryotic cells to confirm that the mutation conferred constitutive activation (Fig. 2).

Indeed basal cAMP production was increased with transfection of the mutated receptor compared with transfection of the wild type $(6,13,22,25)$. The mutant receptors retained their ability to respond to $\mathrm{TSH}$ as indicated by the increased production of cAMP induced by TSH. A control to make sure that the expression levels of the transfected receptors were similar for the mutated and the wild type receptors, consisted of either quantifying the binding sites of radiolabeled TSH or of directly quantifying the receptors $(6,13,22,25)$. Basal inositol phosphate production was usually not found to be increased when the mutated receptor was transfected $(6,16,18,20,25)$. Differential effects of individual mutations on stimulation by TSH of cAMP or inositol phosphate production suggest that individual mutant receptors may achieve different active conformations, with different abilities to couple and activate 
one or both transduction pathways $(6,13,16,22,25)$. So far the reported germline mutations are mainly (with the exception of the recent report by Kopp et al. (29)) located in the transmembrane segments, the majority of them affecting highly conserved segments with respect to the other glycoprotein hormone receptors $(6$, $13,16,22,25)$. The somatic mutations of the TSH receptor gene detected in thyroid adenomas are more dispersed. The meaning of this fact may become clearer as more data are accumulated. A model has been proposed by which the TSH receptor isomerizes between an active and an inactive state; the naturally occurring somatic or germline mutations would act by shifting the equilibrium toward the active conformation of the receptor in the absence of the ligand $(4,18)$. This results in constitutive activation of the cAMP pathway in all cases, but only few mutations result in an additional increase of inositol phosphate accumulation $(4,18)$. Of interest is the fact that the same mutations have been observed, in at least three instances, as germline and somatic mutations at several residues, being responsible for a very aggressive phenotype in the case of its congenital expression, leading to the conclusion that some additional factors, apart from the type of mutation, may play a role in their expression, iodine intake being one potential such factor $(25,34)$.

An in vivo approach was also used to confirm that hyperfunction of the hyperplastic thyroid tissue of patients suffering from toxic hyperplasia due to mutations of the TSH receptor was TSH independent (35). Grafting thyroid tissue from toxic hyperplastic thyroid and from toxic nodules into nude mice led to an increase of thyroid hormone levels, to a decrease of TSH levels, weight loss and signs of thyrotoxicosis in the mice and subsequently to death of the grafted mice, whereas grafting of thyroid tissue from patients with Graves' disease led to quiescence of the grafted tissue $(24,35)$. This demonstrated convincingly the TSH-independent mechanism of this form of hyperthyroidism and is consistent with the constitutive activation of the TSH receptor found in these cases $(13,22)$.

\section{Conclusion}

Following the cloning of the TSH receptor gene, various forms of hyperthyroidism have been explained at the molecular level by detecting activating mutations in this gene. Germline mutations are found in hereditary hyperthyroidism, de novo germline mutations can cause sporadic congenital hyperthyroidism, and somatic mutations are found in the majority of toxic adenomas (5). The discovery of these mutations leading to constitutive activation of the TSH receptor not only help to elucidate some forms of thyroid autonomy, but they also deepen our understanding of the structure-function relationship of the TSH hormone receptor.

\section{References}

1 Parmentier M, Libert F, Maenhaut C, Lefort A, Gerard C, Perret J, Van Sande J, Dumont JE \& Vassart G. Molecular cloning of the thyrotropin receptor. Science 1989246 1620-1622.

2 Vassart G \& Dumont JE. The thyrotropin receptor and the regulation of thyrocyte function and growth. Endocrine Reviews 199213 596-611.

3 Gross B, Misrahi M, Sar S \& Milgrom E. Composite structure of the human thyrotropin receptor gene. Biochemical and Biophysical Research Communications 1991 177 679-687.

4 Tonacchera M, Van Sande J, Parma J, Duprez L, Cetani F, Costagliola S, Dumont JE \& Vassart G. TSH receptor and disease. Clinical Endocrinology 199644 621-633.

5 Dremier S, Coppee F, Delange F, Vassart G, Dumont JE \& Van Sande J. Thyroid autonomy: mechanism and clinical effects. Clinical review 84. Journal of Clinical Endocrinology and Metabolism $1996124187-4193$.

6 De Roux N, Polak M, Couet J, Leger J, Czernichow P, Milgrom E \& Misrahi M. A neomutation of the thyroid-stimulating hormone receptor in a severe neonatal hyperthyroidism. Journal of Clinical Endocrinology and Metabolism 199681 2023-2026.

7 Paschke R \& Ludgate M. The thyrotropin receptor in thyroid diseases. New England Journal of Medicine 1997337 1675-1681.

8 Wess J. G-protein-coupled receptors: molecular mechanisms involved in receptor activation and selectivity of G-protein recognition. FASEB Journal 199711 346-354.

9 Laurent E, Mockel J, Van Sande J, Graff I \& Dumont JE. Dual activation by thyrotropin of the phospholipase $\mathrm{C}$ and cyclic AMP cascades in human thyroid. Molecular and Cellular Endocrinology 198752 273-278.

10 Van Sande J, Raspe E, Perret J, Lejune C, Maenhaut C, Vassart G \& Dumont JE. Thyrotropin activates both the cAMP and the PIP2 cascades in CHO-K1 cells expressing the human cDNA of thyrotropin receptor. Molecular and Cellular Endocrinology 1990 74 R1-R6.

11 Allgeier A, Offermans S, Van Sande J, Spicher K, Schultz G \& Dumont JE. The human thyrotropin receptor activates G-protein Gs and Gq11. Journal of Biological Chemistry $199426913733-$ 13735.

12 Corvilan B, Laurent B, Lecomte M, Van Sande J \& Dumont JE. Role of the cyclic adenosine $3^{\prime}-5^{\prime}$ monophosphate and the phosphatidylinositol- $\mathrm{Ca}^{2+}$ cascade in mediating the effects of thyrotropin and iodide on hormone synthesis and secretion in human thyroid slices. Journal of Clinical Endocrinology and Metabolism 199479 152-159.

13 Parma J, Duprez L, Van Sande J, Cochaux P, Gervy C, Mockel J, Dumont JE \& Vassart G. Somatic mutations in the thyrotropin receptor gene cause hyperfunctioning thyroid adenomas. Nature $1993365649-651$.

14 Porcellini A, Ciullo I, Laviola L, Amabile G, Fenzi G \& Avvedimento VE. Novel mutations of thyrotropin receptor gene in thyroid hyperfunctioning adenomas. Journal of Clinical Endocrinology and Metabolism 199479 657-661.

15 Paschke R, Tonacchera M, Van Sande J, Parma J \& Vassart G. Identification and functional characterization of two new somatic mutations causing constitutive activation of the TSH receptor in hyperfunctioning autonomous adenomas of the thyroid. Journal of Clinical Endocrinology and Metabolism 199479 1785-1789.

16 Tonacchera M, Van Sande J, Cetani F, Swillens S, Schvartz C, Winiszewski P, Portmann L, Dumont JE, Vassart G \& Parma J. Functional characteristics of three new germline mutations of the thyrotropin receptor gene causing autosomal dominant toxic thyroid hyperplasia. Journal of Clinical Endocrinology and Metabolism 199681 547-554.

17 Derwahl M. TSH receptor and Gs-alpha gene mutations in the pathogenesis of toxic thyroid adenomas - a note of caution. Journal of Clinical Endocrinology and Metabolism 199681 27832785.

18 Parma J, Van Sande J, Swillens S, Tonacchera M, Dumont JE \& Vassart G. Somatic mutations causing constitutive activity of the 
TSH receptor are the major cause of hyperfunctional thyroid adenomas: identification of additional mutations activating both the cAMP and inositol phosphate-Ca ${ }^{++}$cascades. Molecular Endocrinology 19959 725-733.

19 Russo D, Arturi F, Suarez HG, Schlumberger M, Du Villard JA, Crocetti U \& Filetti S. Thyrotropin receptor gene alterations in thyroid hyperfunctioning adenomas. Journal of Clinical Endocrinology and Metabolism 199681 1548-1551.

20 Parma J, Duprez L, Van Sande J, Hermans J, Rocmans P, Van Vliet G, Costagliola S, Rodien P, Dumont JE \& Vassart G. Diversity and prevalence of somatic mutations in the thyrotropin receptor and Gs-alpha gene as a cause of toxic thyroid adenomas. Journal of Clinical Endocrinology and Metabolism 199782 26952701.

21 Thomas JL, Leclère J, Hartemann P, Duheille J, Orgiazzi J, Petersen M, Janot C \& Guedenet JC. Familial hyperthyroidism without evidence of autoimmunity. Acta Endocrinologica $1982100512-$ 518.

22 Duprez L, Parma J, Van Sande J, Allgeir A, Leclère J, Schwartz, Delisle MJ, Decoulx M, Orgiazzi J, Dumont J \& Vassart G. Germline mutations in the thyrotropin receptor gene cause non-autosomal dominant hyperthyroidism. Nature Genetics 19947 396-401.

23 Schwab KO, Sohlemann P, Gerlich M, Broecker M, Petrykowsk WV, Holzapfel HP, Paschke R, Gruters A \& Derwahl M. Mutation of the TSH receptor as a cause of congenital hyperthyroidism. Experimental and Clinical Endocrinology and Diabetes 1996104 124-128.

24 Leclère J, Bene MC, Aubert V, Klein M, Pascal-Vigneron V, Weryha $\mathrm{G} \&$ Faure G. Clinical consequences of activating mutations of TSH receptor, the concept of toxic hyperplasia. Hormone Research $199747158-162$.

25 Kopp P, Van Sande J, Parma J, Duprez L, Gerber H, Joss E, Jameson JL, Dumont JE \& Vassart G. Congenital hyperthyroidism caused by a mutation in the thyrotropin receptor gene. New England Journal of Medicine 1995332 150-154.

26 Holzapfel HP, Wonerow P, Von Petrykowski W, Henschen M, Scherbaum WA \& Paschke R. Sporadic congenital hyperthyroidism due to a spontaneous germline mutation in the thyrotropin receptor gene. Journal of Clinical Endocrinology and Metabolism $1997823879-3884$.
27 Crisp MS, Lane C, Halliwell M, Wynford-Thomas D \& Ludgate M. Thyrotropin receptor transcripts in human adipose tissue. Journal of Clinical Endocrinology and Metabolism 199782 2003-2005.

28 Duprez L, Parma J, Costagliola S, Hermans J, Van Sande J, Dumont JE \& Vassart G. Constitutive activation of the TSH receptor by spontaneous mutations affecting the N-terminal extracellular domain. FEBS Letters 1997409 469-474.

29 Kopp P, Muirhead S, Jourdain N, Gu WX, Jameson JL \& Rodd C. Congenital hyperthyroidism caused by a solitary toxic adenoma harboring a novel somatic mutation (serine281isoleucine) in the extracellular domain of the thyrotropin receptor. Journal of Clinical Investigation $19971001634-1639$.

30 Kopp P, Jameson JL \& Roe TF. Congenital nonautoimmune hyperthyroidism in a nonidentical twin caused by a sporadic germline mutation in the thyrotropin receptor gene. Thyroid 1997 $7765-770$

31 Hollingsworth D, Mabry C \& Eckerd JM. Hereditary aspects of Graves disease in infancy and childhood. Journal of Pediatrics 1972 $81446-459$.

32 Hollingsworth D \& Mabry C. Congenital Graves disease. Four familial cases with long-term follow-up and perspective. American Journal of Disabled Children 1976130 148-155.

33 Cotecchia S, Exum S, Caron MG \& Lefkowitz RJ. Regions of the alpha 1-adrenergic receptor involved in coupling to phosphatidylinositol hydrolysis and enhanced sensitivity of biological function. Proceedings of the National Academy of Sciences of the USA 199087 2896-2900.

34 Van Sande J, Parma J, Tonacchera M, Dumont J \& Vassart G. Somatic and germline mutations of the TSH receptor gene in thyroid diseases. Journal of Clinical Endocrinology and Metabolism $1995802577-2585$.

35 Leclère J, Bene MC, Duprez A, Faure G, Thomas JL, Vignaud M \& Burlet C. Behaviour of thyroid tissue from patients with Graves disease in nude mice. Journal of Clinical Endocrinology and Metabolism 198459 175-177.

Received 19 November 1997

Accepted 6 January 1998 